\title{
Insights into molecular pathways of endometriosis and endometriosis-related ovarian carcinoma
}

\author{
IOANA PĂVĂLEANU ${ }^{1)}$, LUdMILA LOZNEANU²), RALUCA ANCA BALAN²), Simona ElizA GiUŞCĂ ${ }^{3)}$, \\ ELENA-ROXANA AVĂDĂNEI ${ }^{2)}$, IRINA-DRAGA CĂRUNTU2), CORNELIA AMĂLINEI ${ }^{2,4)}$ \\ 1) Department of Mother and Child Medicine, Grigore T. Popa University of Medicine and Pharmacy, Iaşi, Romania \\ 2) Department of Morphofunctional Sciences I - Histology, Grigore T. Popa University of Medicine and Pharmacy, Iaşi, Romania \\ 3) Department of Morphofunctional Sciences I - Pathology, Grigore T. Popa University of Medicine and Pharmacy, Iaşi, Romania \\ 4) Department of Histopathology, Institute of Legal Medicine, Iaşi, Romania
}

\begin{abstract}
Background: Endometriosis is a benign estrogen-dependent gynecological disease involving components of the female genital tract (uterus, Fallopian tubes, ovaries, large, round, and utero-sacral ligaments) and intra- and extraperitoneal regions. Since the moment of its etiopathogeny has been identified, the intrinsic capacity of endometriosis malignant transformation has been hypothesized. Patients, Materials and Methods: Our study included a total number of 50 patients diagnosed with endometriosis ( 31 cases) and endometriosis-related ovarian carcinoma (EOC) (19 cases). A clinicopathological and immunohistochemical study directed towards the detection of atypical transition lesions and the similitudes in epithelial-mesenchymal transition (EMT) phenomenon [E-cadherin/ $\beta$-catenin/cytokeratin 18 (CK18)], apoptosis [B-cell lymphoma 2 (Bcl-2)/Bcl-2-associated X (Bax)], and hormonal dynamics mirrored by the immunoexpression of estrogen receptor (ER) and progesterone receptor (PR) in endometriosis and EOC glands and stroma has been performed. Results: Our study showed a higher immunoexpression of $\mathrm{CK} 18$ and E-cadherin in endometriosis than in neoplastic counterparts, while $\beta$-catenin had a stronger immunoexpression in tumors compared with endometriotic areas, with statistically significant differences between the studied groups. Bcl-2/Bax higher rate in endometriosis had a statistically significant association to a more aggressive tumor behavior $(p=0.020)$. ER immunoexpression was stronger in endometriosis, with less negative scores compared to EOC, while PR immunoexpression was stronger in endometriosis, with a lower percent of negative scores compared to EOC. PR immunostaining was correlated to ovarian location of endometriosis $(p=0.004)$ and tumor grade of EOC ( $p=0.027)$. Stromal ER and PR immunoexpression has been significantly lower in endometriosis in comparison to tumor stroma $(p=0.001)$ and PR stromal immunoexpression had been higher in more differentiated tumors compared to less differentiated types $(p=0.005)$. Conclusions: Our study supports that endometriosis is a precursor of EOC by the identification and the coexistence of both lesions in the investigated cases, the identification of intermediate lesions, as well as the expression of EMT immunomarkers, along with apoptosis and steroid receptors immunoexpression.
\end{abstract}

Keywords: endometriosis, endometriosis-related ovarian carcinoma, epithelial-mesenchymal transition, apoptosis, steroid hormones.

\section{Introduction}

Although endometriosis has been described in 19th century, it remains an enigmatic entity, because of its complex etiopathogeny, lack of specific diagnostic markers, and its potential association with specific malignancies. Both surgical and medical techniques are not addressed to etiology but to symptomatology. In this context, recurrences and symptoms persistence are frequently registered, making endometriosis a debilitating disease.

This disease is now considered to have a complex determinism, involving genetic, epigenetic, immunological, proteasic, angiogenic, anti-apoptotic, and proliferative factors that confer multiple facets to the condition and that require a multimodal treatment approach.

In an effort to elucidate the pathogenesis of endometriosis, many theories as retrograde implantation, coelomic metaplasia, induction of endometrial proliferation, embryonic remnants, vascular and lymphatic metastasis, involvement of stem cells from either bone marrow or endothelial progenitors, have been proposed over the years, without reaching a consensus on the mechanism of producing this disease, but considering that it is actually a combination of these mechanisms and accordingly the pathogenesis of endometriosis being multi-factorial and multi-compartmental [1-3].

The malignant transformation of endometriosis is well known [4] and is attributed to two possible mechanisms: either endometriotic implants may directly undergo malignant transformation, or both processes share the same precursor mechanisms and/or predisposing factors with evolutionary molecular pathways divergence [5].

Moreover, based on genomics, transcriptomics, and proteomics, by correlation between genetic mechanisms related to endometriosis transition to malignancy, new algorithms of diagnosis and therapy can be achieved. Accordingly, a special focus has been given to search a possible similar molecular model in both diseases. Thus, the identification of some key molecules of endometriosis and endometriosis-related ovarian carcinoma (EOC) pathogenesis, one or more mechanisms could be validated.

In general, in the mechanism of implantation, three

This is an open-access article distributed under the terms of a Creative Commons Attribution-NonCommercial-ShareAlike 4.0 International Public License, which permits unrestricted use, adaptation, distribution and reproduction in any medium, non-commercially, provided the new creations are licensed under identical terms as the original work and the original work is properly cited. 
phenomena are succeeding, namely, apposition, adhesion, and invasion [6]. During these phenomena dynamics, several adhesion molecules are involved, such as cadherins, selectins, integrins, galectins, heparan sulphate, and trophinin-tastin-bystin complex [6]. Considering the role of the process of epithelial-mesenchymal transition (EMT), added to its opposite mechanism, of mesenchymalepithelial transition (MET) in endometriosis, E-cadherin, $\beta$-catenin, and cytokeratin 18 (CK18) are known to be useful markers in the study of endometriosis, demonstrating the initiation of early E-cadherin- $\beta$-catenin complex mutations in the EMT process. It is estimated that $\beta$-catenin mutations represent an early event in endometriotic-dependent ovarian carcinogenesis and CK18 expression is correlated with EOC stage progression along with EMT, as the malignant process is extending [7].

Apoptosis represents a component of tumor growth, considering its antagonism to cellular proliferation [8] and that it is frequently inhibited in variable types of tumors [9]. This process is prevented in malignant cells and is correlated to carcinogenesis $[5,10]$, being associated to malignant transformation in ovarian tumors [11], to high-grade tumors, and with a poor prognosis [12, 13]. Moreover, this process is associated to high-grade tumors, and with a poor prognosis in ovarian tumors $[12,13]$. B-cell lymphoma 2 (Bcl-2) family maintains the balance between apoptosis and its inhibition, by pro- and antiapoptotic molecules, in functional antagonism [8, 14, 15]. An apoptotic evasion mechanism has been proven, allowing the development of ectopic implants, in endometriosis. Furthermore, $\mathrm{Bcl}-2 / \mathrm{Bcl}-2$-associated $\mathrm{X}(\mathrm{Bax})$ ratio is progressively increasing in EOC compared to endometriosis [16].

Steroid hormones and hormone-like substances have a major role in endometrium normal function and their unbalance results in different endometrial diseases, including endometriosis. Numerous studies have demonstrated that estrogen receptor (ER) and progesterone receptor (PR) immunoexpressions are associated with endometriosis and EOC $[17,18]$.

As a hormone-related pathology, endometriosis has an enhanced level of estrogens within the endometrial tissue, associated with an increased rate between ER- $\beta$ and ER- $\alpha$, thus resulting in a low PR immunoexpression [19, 20]. Progesterone effect, modulated by the expression of both isoforms of the specific receptor, PR-A and PR-B, is involved in endometriosis and endometriosis-related carcinomas pathogeny $[21,22]$. It has been demonstrated that the cytokines production, in endometriosis, is the modified response to progesterone, with a characteristic decreased PR-B/PR-A ratio and reduced immunoreactivity of PR-B [19, 23]. In a close correlation to PR immunoexpression, ER immunoexpression has a major importance in clinicopathological manifestations of ovarian carcinoma (OC), including in that associated to endometriosis [21, 22]. Thus, it seems that alteration of steroid receptor immunoexpression is correlated to ovarian endometriosis and endometriosis-related carcinogenesis.

\section{Aim}

Our study compared a group of cases with endometriosis and a group with ovarian malignancies associated with endometriosis in order to evaluate the immunoexpression of some molecules of the EMT process (E-cadherin, $\beta$ catenin, and CK18) associated to apoptotic immunomarkers (Bcl-2 and Bax) and hormonal profile (ER and PR), providing correlations with molecular changes sequence during the pathogenic mechanism of these diseases.

\section{ㅁ Patients, Materials and Methods}

\section{Patients}

We conducted a retrospective study on 50 patients diagnosed with endometriosis and EOC. Patients were divided in two groups. The first group comprised of 31 cases with endometriosis, which were diagnosed in the Department of Histopathology of the Elena Doamna Clinical Hospital in Iași, Romania, between January 2005 and April 2017. The second group consisted of 19 cases of OCs associated with endometriotic lesions, diagnosed between February 2013 and January 2016, in the Regional Institute of Oncology, Iaşi, which have been treated by total radical hysterectomy and pelvic lymphadenectomy.

The relevant clinicopathological data have been collected from the medical records in both groups (Table 1). Accordingly, age, parity, menopausal status, type (unifocal versus multifocal and cystic lesions), site (ovarian, cervical, tubal, and cutaneous), and associations with other gynecological pathologies have been recorded in endometriosis group. Supplementary to age, parity, menopausal status, data regarding tumor size, ovarian capsular invasion, histological types of EOC, International Federation of Gynecology and Obstetrics (Fédération Internationale de Gynécologie et d'Obstétrique - FIGO), tumor, node, metastasis (TNM) stages, and cancer antigen 125 (CA125) serum values have been recorded in EOC group.

Table 1 - The main clinicopathological features in the study groups

\begin{tabular}{|c|c|c|c|c|c|c|c|c|c|c|}
\hline \multicolumn{11}{|c|}{ Endometriosis group ( $n=31$ cases; median age: 36.61 years) } \\
\hline \multicolumn{3}{|c|}{ Endometriotic foci } & \multicolumn{2}{|c|}{ Parity } & \multicolumn{2}{|c|}{ Menstrual status } & \multicolumn{4}{|c|}{ Associated lesions } \\
\hline Parietal/mural & Ovarian uni/bilateral & Mixed-multifocal & Mul & ous & Menop & I status & ULM & $A D$ & $O C$ & CC \\
\hline 3 & 22 & 6 & & & & & 7 & 10 & 5 & 9 \\
\hline \multicolumn{11}{|c|}{ Epithelial ovarian tumors associated with endometriosis ( $n=19$ cases; median age: 59.10 years) } \\
\hline \multicolumn{2}{|c|}{ Histological types } & & \multicolumn{2}{|c|}{ FIGO stages } & \multicolumn{3}{|c|}{ Histological grading } & \multicolumn{3}{|c|}{ TNM system } \\
\hline $\begin{array}{c}\text { Endometrioid } \\
\text { carcinoma }\end{array}$ & $\begin{array}{c}\text { Non-endometric } \\
\text { carcinoma }\end{array}$ & oid & II & III & Gl & Gll & GIII & $T 1$ & $T 2$ & T3 \\
\hline 8 & 11 & 4 & 6 & 9 & 1 & 6 & 12 & 5 & 6 & 8 \\
\hline
\end{tabular}

AD: Adenomyosis; CC: Chronic cervicitis; FIGO: International Federation of Gynecology and Obstetrics (Fédération Internationale de Gynécologie et d'Obstétrique); OC: Ovarian cysts; TNM: Tumor, node, metastasis; ULM: Uterine leiomyomas. 


\section{Methods}

All cases were investigated by applying the immunohistochemical (IHC) method, using a panel of primary antibodies with the appropriate dilutions (Table 2).

Table 2 - Antibodies types, clones, dilutions, and immunostaining pattern used in the immunohistochemical technique

\begin{tabular}{|c|c|c|c|c|}
\hline Antibody & Type & $\begin{array}{c}\text { Clone / } \\
\text { Manufacturer }\end{array}$ & Dilution & $\begin{array}{l}\text { Immuno- } \\
\text { staining } \\
\text { pattern }\end{array}$ \\
\hline E-cadherin & $\begin{array}{l}\text { Mouse } \\
\text { MoAbs }\end{array}$ & $\begin{array}{c}36 \mathrm{~B} 5 / \\
\text { Novocastra }\end{array}$ & $1 / 50$ & Membrane \\
\hline$\beta$-catenin & $\begin{array}{l}\text { Mouse } \\
\text { MoAbs }\end{array}$ & $\begin{array}{c}\beta \text {-catenin-1 / } \\
\text { Dako }\end{array}$ & $1 / 200$ & $\begin{array}{l}\text { Membrane } \\
\text { and } \\
\text { cytoplasm }\end{array}$ \\
\hline CK18 & $\begin{array}{l}\text { Mouse } \\
\text { MoAbs }\end{array}$ & $\begin{array}{c}\text { DC-10 / } \\
\text { Novocastra }\end{array}$ & $1 / 100$ & Membrane \\
\hline Bax & $\begin{array}{l}\text { Rabbit } \\
\text { PoAbs }\end{array}$ & $\begin{array}{c}\text { Polyclonal / } \\
\text { Dako }\end{array}$ & $1 / 1500$ & Cytoplasm \\
\hline $\mathrm{Bcl}-2$ & $\begin{array}{l}\text { Mouse } \\
\text { MoAbs }\end{array}$ & $\begin{array}{c}\text { Bcl-2/100/D5 / } \\
\text { Novocastra }\end{array}$ & $1 / 80$ & Cytoplasm \\
\hline ER & $\begin{array}{l}\text { Mouse } \\
\text { MoAbs }\end{array}$ & $\begin{array}{c}\text { 6F11 / } \\
\text { Novocastra }\end{array}$ & RTU & Nuclear \\
\hline PR & $\begin{array}{l}\text { Mouse } \\
\text { MoAbs }\end{array}$ & $\begin{array}{c}\text { PGR-312/16 / } \\
\text { Novocastra }\end{array}$ & RTU & Nuclear \\
\hline
\end{tabular}

Bax: Bcl-2-associated X; Bcl-2: B-cell lymphoma 2; CK18: Cytokeratin 18; ER: Estrogen receptor; MoAbs: Monoclonal antibodies; PoAbs: Polyclonal antibodies; PR: Progesterone receptor; RTU: Ready-to-use.

Immunohistochemistry was performed on representative tissues samples of each type of lesion. Serial sections from the corresponding paraffin blocks, of 3-4 $\mu \mathrm{m}$ thickness were cut and placed on slides SuperFrostPlus. The immunostaining was performed using the automated BenchMark XT system (Ventana Medical System, Inc., Tucson, AZ, USA), following standardization.

Negative controls, obtained by replacement of primary antibodies with distilled water, along with positive controls have been simultaneously run.

\section{Semi-quantitative analysis}

Semi-quantitative assessment of IHC reactions was performed using the score systems reported in the literature, for each immunomarker. The differences in quantification methods applied are justified by immunomarkers specific patterns of immunoexpression, which require or not a double measurement (intensity and the percentage of positive cells).

The score systems took into consideration the immunostaining intensity multiplied with the percent of positive cells with a cut-off of $4(<4$ - negative and low score and $\geq 4$ - high score). The immunostaining intensity for all investigated immunomarkers was considered as following: 3 as a strong intensity, 2 as moderate, 1 as weak, and 0 as negative immunostaining.

The percentage of E-cadherin immunopositive cells was classified as 1 for $\leq 10 \%, 2$ for $11-50 \%$, and 3 for $\geq 50 \%$. The percentage of cells which displayed a $\beta$-catenin immunopositivity was scored as following: 1 for $<10 \%$, 2 for $10-30 \%, 3$ for $30-50 \%$, and 4 for $>50 \%$ positive cells. The percentage of cells which showed CK18 immunopositivity was evaluated as 4 in $>76-100 \%, 3$ in $51-75 \%, 2$ in $26-50 \%, 1$ in $6-25 \%$, and 0 in $0-5 \%$ positive cells [7, 24, 25]. For Bcl-2 analysis, the percentage of immunopositivity was scored as 4 in $>75 \%, 3$ in $51-75 \%, 2$ in $26-50 \%, 1$ in $1-25 \%$, and 0 in no positive cells. Score
0 has been considered as negative, and scores $1-4$ have been considered as positive [26].

A score which was exclusively based on the immunostaining intensity has been used for Bax and accordingly, the cases have been divided into three categories, as follows: weak intensity $(+)$, moderate intensity $(++)$, and strong positivity $(+++)[27]$.

Allred score [28, 29], based on index of positive cells, has been used for ER and PR immunostaining epithelial quantification, with the score considered as 0 : none, 1: $<1 / 100(<1 \%), 2: 1 / 100-1 / 10(1-10 \%), 3:>1 / 10-1 / 3$ (10-33\%), 4: $>1 / 3-2 / 3(33-66 \%), 5:>2 / 3(>66 \%)$, added to immunostaining intensity. ER and PR were also qualitatively assessed in stromal cells.

\section{Statistical analysis}

Statistical data processing was performed by Statistical Package for the Social Sciences (SPSS) v. 19.0 (IBM SPSS Statistics), with mean, standard deviation, and the categorical variables as number $(\%)$ for continuous variables. The degree of correlation between the markers investigated and the clinicopathological findings was achieved by $\chi^{2}$ (chi-squared) test or Fisher's exact test. In order to evaluate continuous variables, Student's $t$-test or the Wilcoxon rank-sum test were performed, with significant values in $p<0.05$.

\section{口 Results}

\section{Results in endometriosis}

E-cadherin expression had a homogeneous, membrane distribution throughout the entire endometriosis foci in glandular epithelium and had been also noticed in few stromal cells. The assessment of E-cadherin showed positive immunoexpression in all cases, with moderate intensity in $18(58.06 \%)$ cases and strong intensity in $13(41.93 \%)$ cases (Figure 1A). The percentage of positive cells was higher than $50 \%$ in $23(77.41 \%)$ cases (Table 3$)$.

In endometriotic area, glandular epithelium showed homogeneous, membrane and cytoplasmic $\beta$-catenin immunoexpression (Figure 2). $\beta$-catenin immunostaining intensity was moderate in $14(45.16 \%)$ cases and strong in $17(54.83 \%)$ cases. The percentage of positive cells was over $50 \%$ in $14(45.16 \%)$ cases. An increased $\beta$-catenin immunoexpression could be observed as well in the periglandular stromal cells.

Most of epithelial cells in the endometriotic foci were strongly positive for CK18 and only a small proportion of cells, immunostained moderate or weak, CK18 intensity being moderate and weak in nine $(29.03 \%)$ cases and strong in $22(70.96 \%)$ cases. Immunoexpression of CK18 was found to be homogeneous, with a higher intensity than E-cadherin and $\beta$-catenin immunoexpression. The percentage of CK18 immunopositive cells was higher than $50 \%$ in almost all cases [29 (93.54\%) cases] (Figure 3).

The correlation analysis between EMT immunomarkers expression (E-cadherin, $\beta$-catenin, and CK18) did not reveal any statistically significant associations.

Bcl-2 and Bax had a variable cytoplasmic distribution, in the endometriosis foci, though some heterogeneous areas were focally identified. Bcl-2 immunoexpression has been negative in $15(48.38 \%)$ cases and positive in 16 $(51.61 \%)$ cases of endometriosis (Figure 4), while Bax 
showed negative or weak immunoexpression in 14 (45.16\%) cases of endometriosis and moderate or high immunoexpression in 17 (54.83\%) cases (Figure 5). The percentage of Bcl-2 immunopositive cells was over $50 \%$ in two (6.45\%) cases (Table 3 ).

A negative Bcl-2 immunoexpression associated a negative Bax immunoexpression in two $(13.33 \%)$ cases and Bax immunopositivity in $13(86.66 \%)$ cases, while cases with positive Bcl-2 immunoexpression associated a negative Bax immunoexpression only in one case $(6.25 \%)$ and Bax immunopositivity in 15 (93.75\%) cases.

Table 3 - Distribution of the investigated immunomarkers in endometriotic and EOC group

\begin{tabular}{|c|c|c|c|c|c|c|c|c|}
\hline \multirow{2}{*}{$\begin{array}{l}\text { Immuno- } \\
\text { markers }\end{array}$} & \multicolumn{3}{|c|}{ Endometriotic group ( $n=31$ cases) } & $\begin{array}{c}\text { CP } \\
\text { features }\end{array}$ & \multicolumn{2}{|c|}{ EOC group ( $n=19$ cases) } & \multirow{2}{*}{\multicolumn{2}{|c|}{$\begin{array}{r}\begin{array}{c}\text { CP } \\
\text { features }\end{array} \\
p<0.05\end{array}$}} \\
\hline & Distribution & Intensity (\%) & \multicolumn{2}{|c|}{$p<0.05$} & Distribution & Intensity (\%) & & \\
\hline E-cadherin & $\begin{array}{l}\text { Homogeneous, } \\
\text { membrane } \\
\text { glandular } \\
\text { epithelium (all) } \\
\text { and stromal } \\
\text { cells (rare) } \\
\end{array}$ & $\begin{array}{c}\text { Positive (all cases) } \\
\text { Moderate (18 cases) } \\
\text { Strong (13 cases) } \\
\text { Positive cells } \\
\text { (23 cases } />50 \%)\end{array}$ & \multirow{3}{*}{ NSSV } & \multirow{3}{*}{ NSSV } & $\begin{array}{l}\text { Heterogeneous, } \\
\text { membrane }\end{array}$ & $\begin{array}{l}\text { Negative } \\
\text { (all cases) }\end{array}$ & \multirow{2}{*}{$p=0.0001$} & \multirow{3}{*}{ NSSV } \\
\hline$\beta$-catenin & $\begin{array}{l}\text { Homogeneous, } \\
\text { membrane and } \\
\text { cytoplasmic } \\
\text { epithelium (all) } \\
\text { and stromal } \\
\text { cells (rare) }\end{array}$ & $\begin{array}{l}\text { Positive (all cases) } \\
\text { Moderate (14 cases) } \\
\text { Strong (17 cases) } \\
\text { Positive cells } \\
\text { (14 cases } />50 \%)\end{array}$ & & & $\begin{array}{l}\text { Homogeneous, } \\
\text { membrane and } \\
\text { cytoplasmic } \\
\text { epithelium (all) } \\
\text { and stromal } \\
\text { cells } \\
\end{array}$ & $\begin{array}{l}\text { Moderate to weak } \\
\text { (three cases) } \\
\text { Strong (16 cases) } \\
\text { Positive cells } \\
(17 \text { cases } />50 \%)\end{array}$ & & \\
\hline CK18 & $\begin{array}{l}\text { Homogeneous, } \\
\text { membrane } \\
\text { glandular } \\
\text { epithelium (all) } \\
\text { and stromal } \\
\text { cells (rare) }\end{array}$ & $\begin{array}{l}\text { Positive (all cases) } \\
\text { Moderate to weak } \\
\text { (nine cases) } \\
\text { Strong ( } 22 \text { cases) } \\
\text { Positive cells } \\
\text { (29 cases } />50 \%) \\
\end{array}$ & & & $\begin{array}{l}\text { Homogeneous, } \\
\text { membrane } \\
\text { glandular } \\
\text { epithelium (all) } \\
\text { and stromal } \\
\text { cells (rare) }\end{array}$ & $\begin{array}{c}\text { Moderate } \\
\text { (five cases) } \\
\text { Strong }(14 \text { cases) } \\
\text { Positive cells } \\
\text { (14 cases } />70 \%)\end{array}$ & NSSV & \\
\hline \multirow[t]{2}{*}{$\mathrm{Bcl}-2$} & \multirow{3}{*}{$\begin{array}{l}\text { Heterogeneous, } \\
\text { cytoplasmic } \\
\text { glandular } \\
\text { epithelium (all) } \\
\text { and stromal } \\
\text { cells (rare) }\end{array}$} & $\begin{array}{c}\text { Positive (16 cases) } \\
\text { Weak (11 cases) } \\
\text { Moderate } \\
\text { (three cases) }\end{array}$ & \multirow{3}{*}{$p=0.020$} & \multirow{3}{*}{ NSSV } & \multirow{3}{*}{$\begin{array}{c}\text { Heterogeneous, } \\
\text { cytoplasmic, } \\
\text { finely granular } \\
\text { pattern }\end{array}$} & $\begin{array}{l}\text { Weak to moderate } \\
\text { (seven cases) }\end{array}$ & \multirow{3}{*}{ NSSV } & \multirow{3}{*}{ NSSV } \\
\hline & & $\begin{array}{c}\text { Strong } \\
\text { (two cases } />50 \%) \\
\text { Negative }(15 \text { cases) }\end{array}$ & & & & $\begin{array}{c}\text { Negative } \\
\text { (12 cases) }\end{array}$ & & \\
\hline Bax & & $\begin{array}{c}\text { Weak/negative } \\
\text { (14 cases) } \\
\text { Moderate to strong } \\
\text { (17 cases })\end{array}$ & & & & $\begin{array}{c}\text { Strong to moderate } \\
\text { (12 cases) } \\
\text { Negative/weak } \\
\text { (seven cases) }\end{array}$ & & \\
\hline ER & \multirow{2}{*}{$\begin{array}{l}\text { Homogeneous } \\
\text { diffusely nuclear } \\
\text { (glandular } \\
\text { epithelium) }\end{array}$} & $\begin{array}{l}\text { Positive (22 cases) } \\
\text { Negative (nine cases) }\end{array}$ & \multirow[t]{2}{*}{ NSSV } & NSSV & $\begin{array}{l}\text { Homogeneous } \\
\text { (ER)/ } \\
\text { heterogeneous } \\
\text { (PR) }\end{array}$ & $\begin{array}{c}\text { Strong to moderate } \\
\text { (15 cases) } \\
\text { Negative/weak } \\
\text { (four cases) } \\
\end{array}$ & \multirow[t]{2}{*}{ NSSV } & NSSV \\
\hline PR & & $\begin{array}{l}\text { Positive (19 cases) } \\
\text { Negative (12 cases) }\end{array}$ & & $\begin{array}{l}p=0.004 \\
(\mathrm{OE})\end{array}$ & $\begin{array}{c}\text { diffusely nuclear } \\
\text { (glandular } \\
\text { epithelium) }\end{array}$ & $\begin{array}{c}\text { Strong (10 cases) } \\
\text { Negative/weak } \\
\text { (nine cases) }\end{array}$ & & $\begin{array}{c}p=0.027 \\
(\mathrm{TG})\end{array}$ \\
\hline
\end{tabular}

Bax: Bcl-2-associated X; Bcl-2: B-cell lymphoma 2; CK18: Cytokeratin 18; CP: Clinicopathological features; EOC: Endometriosis-related ovarian carcinoma; ER: Estrogen receptor; NSSV: Non-statistically significant values; OE: Ovarian endometriosis; PR: Progesterone receptor; TG: Tumor grade. Student's $t$-test or Wilcoxon rank-sum test, chi-squared test or Fisher's exact test $(p<0.05)$.
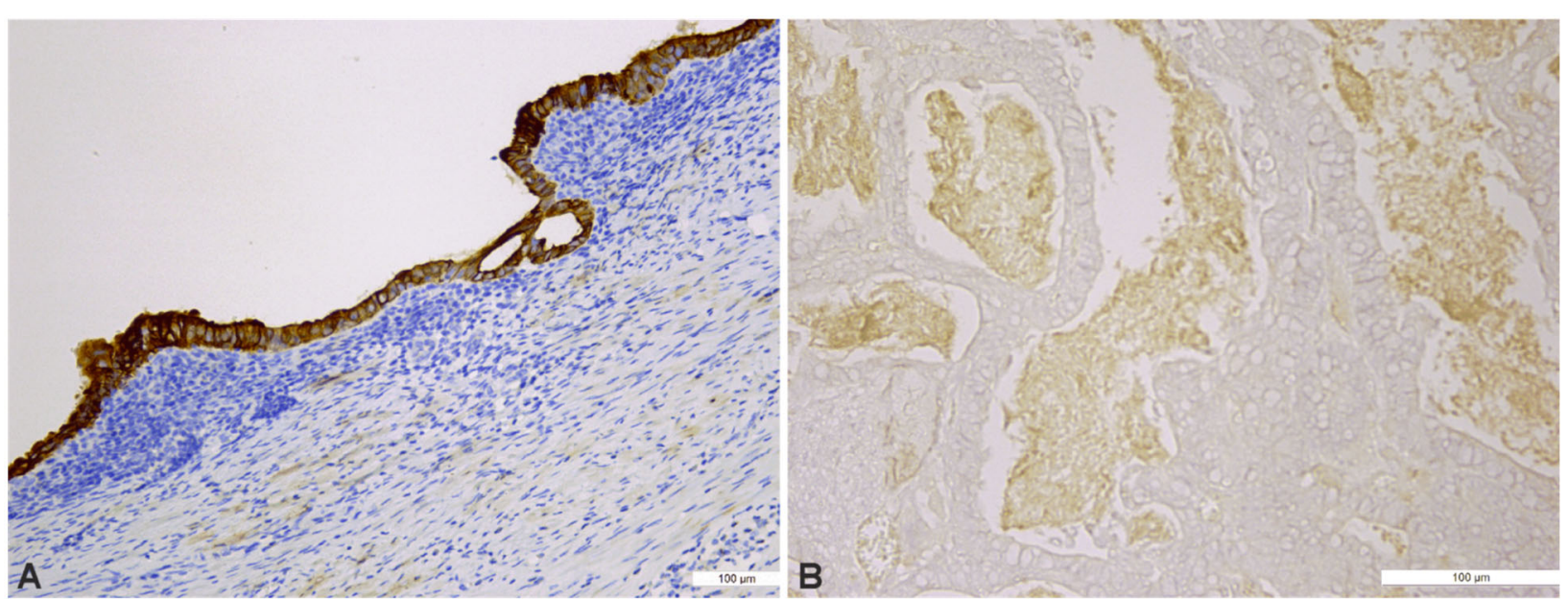

Figure 1 - (A) Positive homogeneous, apical membrane E-cadherin immunoexpression in glandular epithelium of endometriosis; (B) Negative E-cadherin immunoexpression in EOC, with weak positive luminal secretion. Anti-E-cadherin antibody immunostaining: $(A) \times 40 ;(B) \times 200$. EOC: Endometriosis-related ovarian carcinoma. 


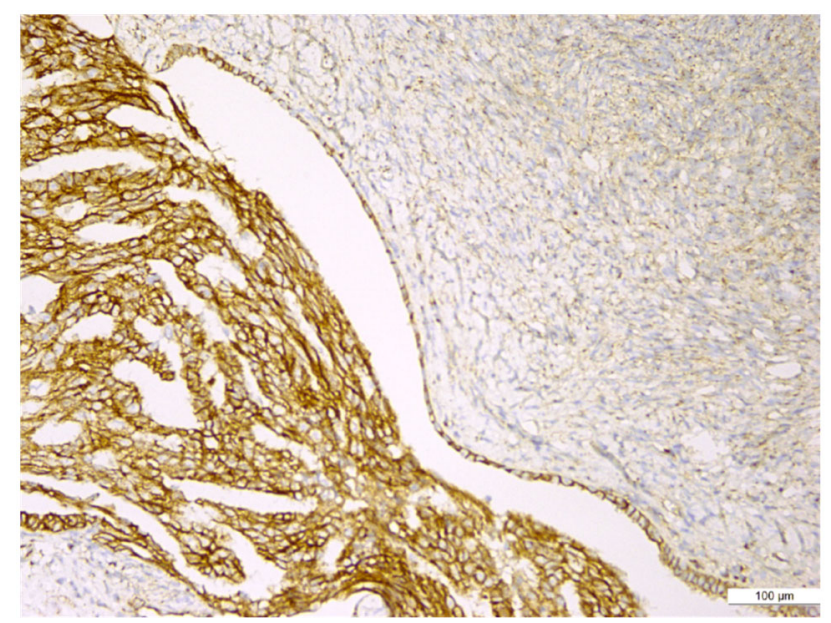

Figure 2 - Strong, homogeneous membrane and cytoplasmic $\beta$-catenin immunoexpression in EOC (left) and

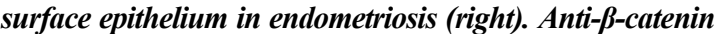
antibody immunostaining, $\times 100$. EOC: Endometriosisrelated ovarian carcinoma.

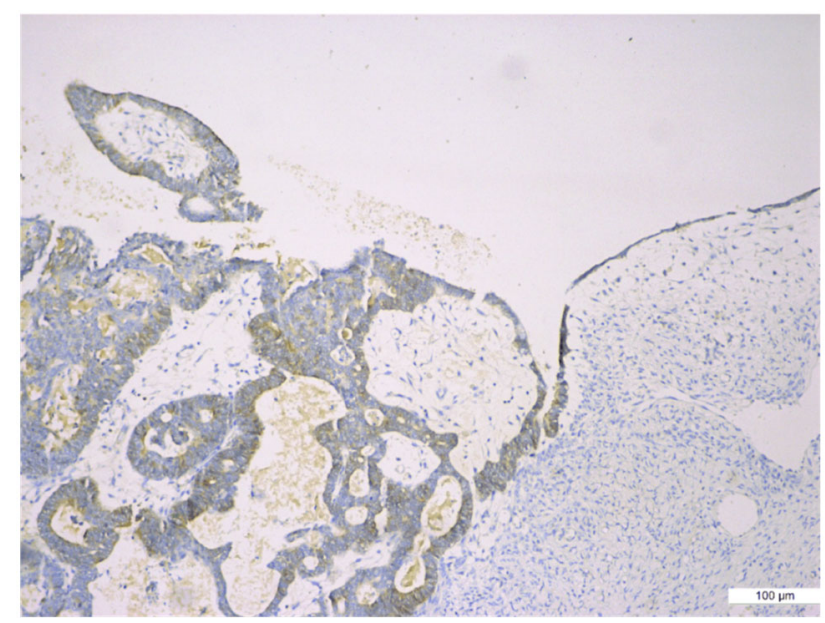

Figure 4 - Moderate intensity, heterogeneous cytoplasmic Bcl-2 immunoexpression in endometriosis (right) and weak to moderate immunoexpression in EOC (left). Anti-Bcl-2 antibody immunostaining, $\times 40$. Bcl-2: B-cell lymphoma 2; EOC: Endometriosis-related ovarian carcinoma.

The statistical correlation analysis revealed statistically significant differences between Bax and Bcl-2 immunoexpression in the endometriosis group $(p=0.020)$. The statistical correlation analysis between Bcl-2 and Bax and clinicopathological factors did not reveal any statistically significant associations.

The immunoexpression of ER and PR was diffusely nuclear and homogeneous through all endometriotic area. ER immunoexpression in endometriotic areas had negative score in nine $(29.03 \%)$ cases and positive score in 22 (70.96\%) cases (Figure 6), while PR revealed negative score in $12(38.70 \%)$ cases and positive score in $19(61.30 \%)$ cases (Figure 7). The statistical correlation analysis between ER immunoexpression and clinicopathological characteristics has not shown any statistically significant associations. The statistical correlation analysis between the percentage of ER immunopositive endometriotic cells and percentage of PR immunopositive cells and clinicopathological factors revealed statistically significant

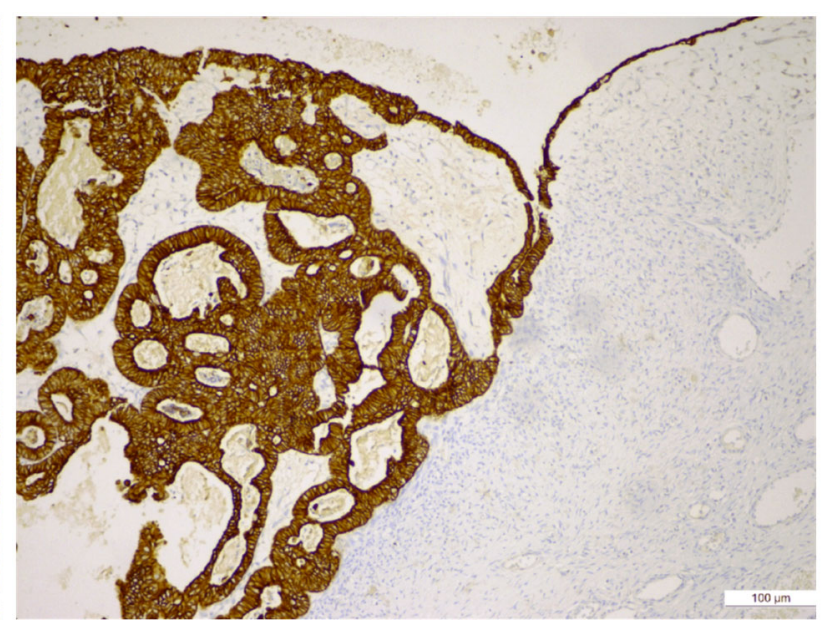

Figure 3 - Limited CK18 immunoexpression in surface epithelium in endometriosis (right) compared to strong, homogenous, diffuse, membrane immunoexpression in EOC area. Anti-CK18 antibody immunostaining, $\times 100$. CK18: Cytokeratin 18; EOC: Endometriosis-related ovarian carcinoma.

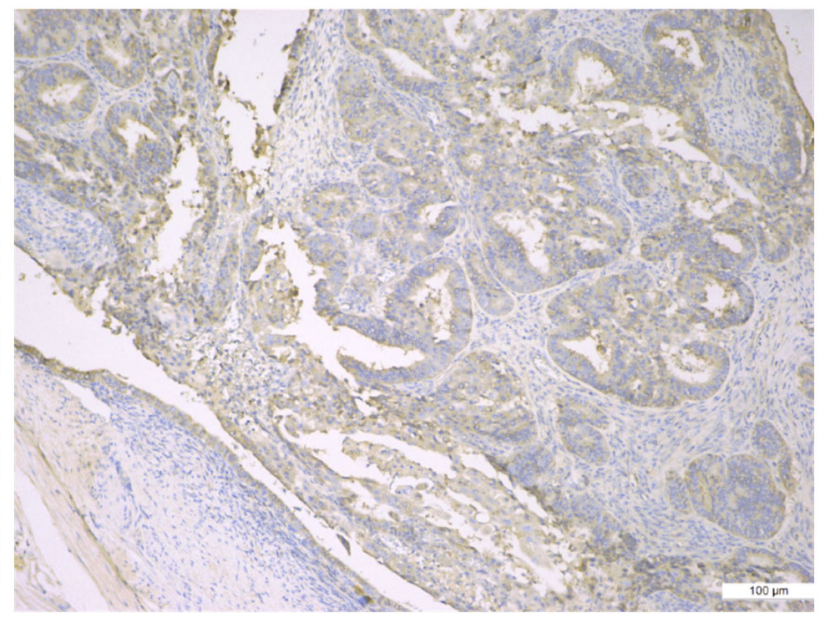

Figure 5 - Bax cytoplasmic weak immunoexpression in EOC (right) compared to moderate cytoplasmic immunoexpression in endometriosis (left). Anti-Bax antibody immunostaining, $\times 100$. Bax: Bcl-2-associated X; Bcl-2: B-cell lymphoma 2; EOC: Endometriosis-related ovarian carcinoma.

differences only in the ovarian location of endometriosis $(p=0.004)$ (Table 3).

We identified also a particular immunoexpression pattern of ER and PR in the stromal cells. According to IHC evaluation of stroma component for both hormonal immunomarkers, the percentage revealed a moderate to strong, heterogeneous immunoexpression, with the following aspects: $10(32.25 \%)$ cases were positive, 21 $(67.74 \%)$ cases had negative ER immunoreaction, while 11 (35.48\%) cases were PR positive and 20 (64.51\%) cases were PR negative.

The statistical correlation analysis between stromal ER/PR immunoexpression and clinicopathological factors (age, parity, menopausal status, lesional type and site, association with other gynecological disease) did not reveal any statistically significant associations.

\section{Results in EOC}

E-cadherin distribution was heterogeneous throughout 
the entire tumor cells, the immunoexpression being weak in $13(68.42 \%)$ cases and moderate in four $(21.05 \%)$ cases (Figure 1B). Although immunohistochemistry revealed a lower percentage of positive cells (less than 40\%) in $13(68 \%)$ cases and a higher one (more than $45 \%$ ) in six $(32 \%)$ cases, all cases have been considered as E-cadherin negative, as their scores have ranged between 0 and 4 . In five $(26.31 \%)$ cases, we noticed a very low positivity percentage $(<10 \%$ of E-cadherin-positive tumor cells), and these cases associated high $\beta$-catenin immunostaining, in more than $50 \%$ of the tumor cells (Table 3 ).

$\beta$-catenin immunoexpression was positive in all cases with moderate and weak intensity in three $(15.78 \%)$ cases and strong in $16(84.21 \%)$ of cases (Figure 2). The percentage of positive cells was over 50\% in $17(89.47 \%)$ cases with scores ranging from 4 to 12 . In tumor cells, $\beta$-catenin showed homogeneous, diffuse expression with a more intense immunostaining compared with E-cadherin (Table 3).

CK18 immunoexpression in all EOC cases had a moderate [five $(26.31 \%)$ cases] or strong intensity [14 $(73.68 \%)$ cases] (Figure 3). For most of the tumor area,

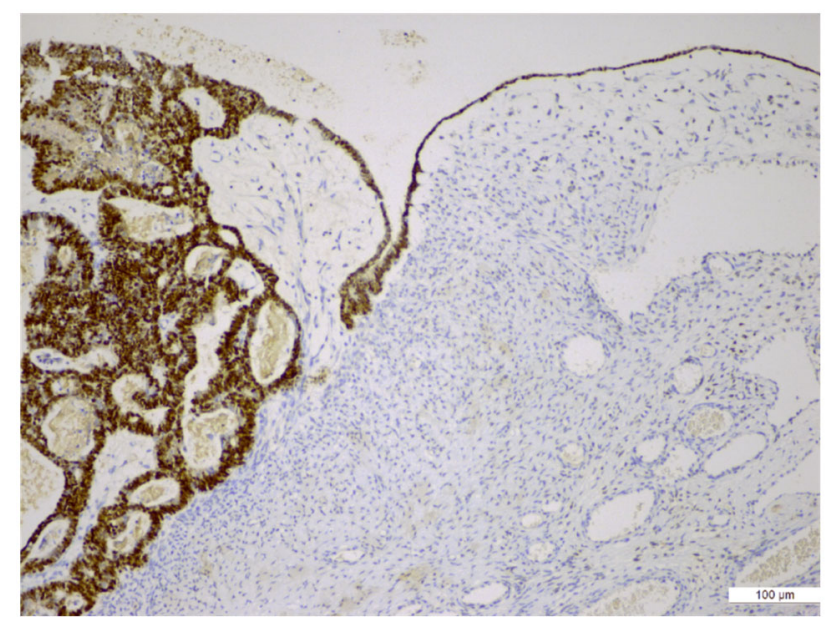

Figure 6 - ER epithelial immunoexpression in endometriosis (right) and contiguous area of EOC (left) with homogeneous, diffuse, nuclear ER immunoexpression. Anti-ER antibody immunostaining, $\times 100$. EOC: Endometriosis-related ovarian carcinoma; ER: Estrogen receptor. the percentage of positive cells was higher than $70 \%$, with homogeneous immunoexpression pattern and higher intensity than E-cadherin and $\beta$-catenin immunoexpression.

The statistical analysis between the EMT immunomarkers investigated in EOC group revealed significant differences only when comparing E-cadherin with $\beta$-catenin $(p=0.0001)$ and also when comparing E-cadherin with CK18 immunoexpression $(p=0.0001)$.

The correlation analysis between EMT immunomarkers (E-cadherin, $\beta$-catenin, and CK18) expression in EOC and clinicopathological characteristics (age, parity, menopausal status, tumor size, ovarian capsular invasion, histological type of EOC, FIGO, TNM stages, and CA125 serum values) did not reveal any statistically significant associations (Table 3).

The statistical analysis between the two studied groups showed significant differences not only for E-cadherin ( $p=0.001)$ but also for the other two EMT immunomarkers, namely $\beta$-catenin $(p=0.000112)$ and CK18 $(p=0.032468)$, in endometriosis versus EOC derived from endometriotic foci (Figure 8).

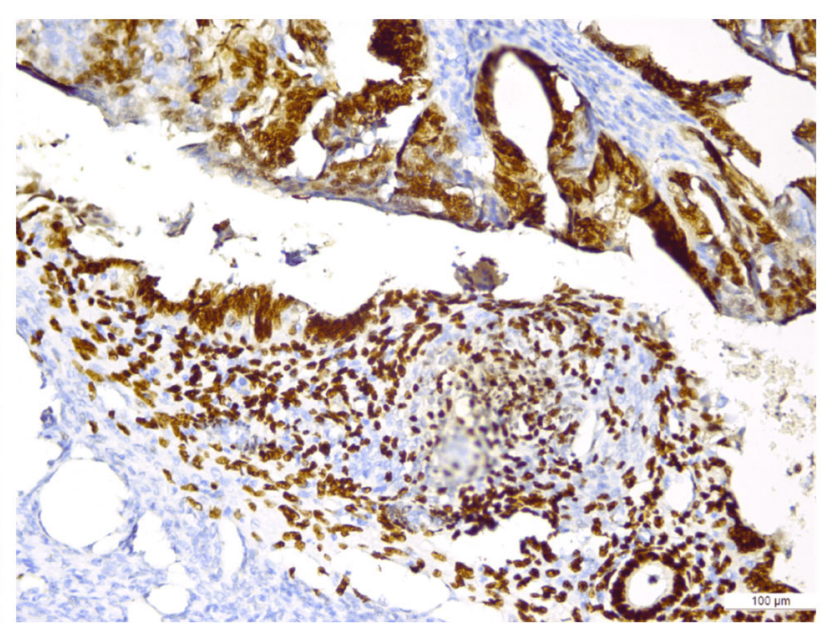

Figure 7 - Diffuse, strong, heterogeneous epithelial and stromal PR immunoexpression in an endometriotic focus (inferior) and in neighboring EOC (superior). Anti-PR antibody immunostaining, $\times 100$. EOC: Endometriosisrelated ovarian carcinoma; PR: Progesterone receptor.

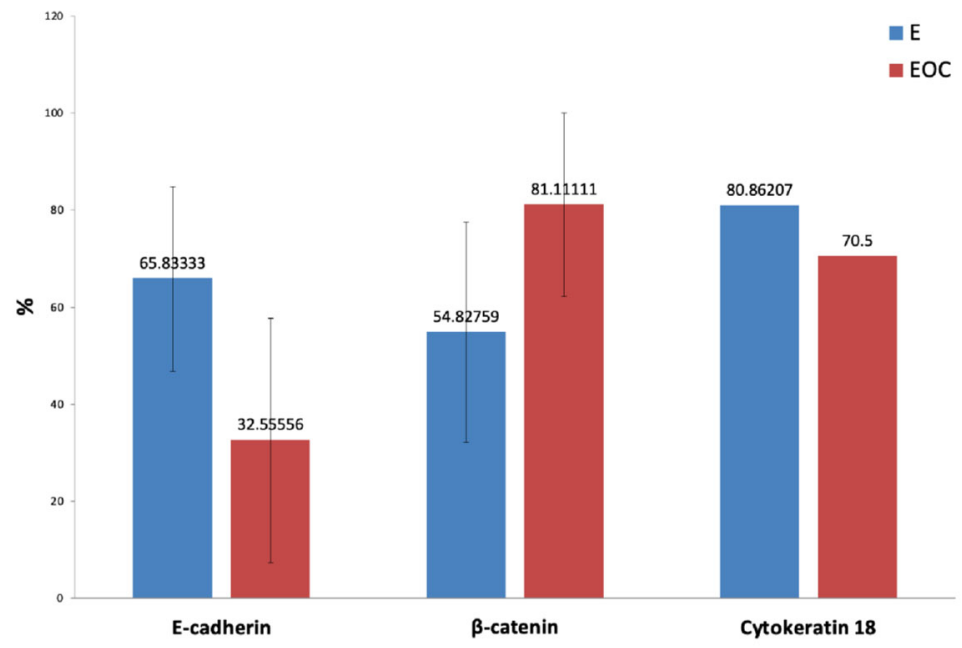

Figure 8 - E-cadherin, $\beta$-catenin, and cytokeratin 18 comparative scores in the study groups. E: Endometriosis; EOC: Endometriosis-related ovarian carcinoma. 
Bcl-2 immunoexpression has been negative in 12 $(63.15 \%)$ cases and weak or moderate positive in seven $(36.84 \%)$ cases of EOC (Figure 4), while Bax showed negative or weak immunoexpression in seven (36.84\%) cases of EOC and moderate or high immunoexpression in $12(63.75 \%)$ cases (Figure 5). Bcl-2 and Bax immunoexpression exhibited a heterogeneous, cytoplasmic, finely granular pattern, in tumor cells.

We observed an interesting immunoexpression pattern of Bcl-2 and Bax, namely groups of tumor cells that were positive for Bcl-2 (seven cases) were negative for Bax (seven cases), while groups of tumor cells that were negative for Bcl-2 (12 cases) were positive for Bax (12 cases). Furthermore, negative Bcl-2 cases associated moderately and increased Bax immunoexpression, whereas Bcl-2 immunopositive cases associated negative or low Bax immunoexpression in half of the cases (Table 3).

Cases with negative $\mathrm{Bcl}-2$ immunoexpression associated Bax negativity in six $(31.57 \%)$ cases and Bax positivity in six $(31.57 \%)$ cases, while cases with positive Bcl-2 immunoexpression associated a negative Bax immunoexpression in one case $(5.26 \%)$ and positive one in seven $(36.84 \%)$ cases. No statistically significant differences have been registered between the immunoexpression of Bax and Bcl-2 in EOC. The statistical correlation analysis between Bcl-2 and Bax immunoexpression and clinicopathological factors did not reveal any statistically significant associations from a statistical point of view.

ER and PR immunopositivity has been noticed in both tumor cells and stroma. ER and PR immunoexpression has been positive, exhibiting a nuclear immunostaining in the tumor cells. The distribution of ER was predominantly homogenous, while PR showed a predominantly heterogeneous immunoexpression (Table 3). ER immunoexpression in epithelial tumor areas had negative score in four $(21.05 \%)$ cases and positive score in 15 (78.94\%) cases (Figure 6), while PR immunoexpression revealed negative score in nine $(47.36 \%)$ cases and a positive score in $10(52.63 \%)$ cases (Figure 7$)$.

For both immunomarkers, ER and PR, we identified a moderate to strong, heterogeneous expression in tumor stroma. ER/PR ratio in stromal cells have been positive in more than $50 \%$ of cases $(n=11 ; 57.89 \%)$. Negative immunoexpression has been registered in eight $(42.10 \%)$ cases.

There have been no statistically significant differences registered between the immunoexpression of ER in EOC and clinicopathological factors (age, parity, menopausal status, tumor size, ovarian capsular invasion, histological type of EOC, FIGO, TNM stages, and CA125 serum values).

Regarding PR immunoexpression, significant differences have been registered between more differentiated tumors compared to less differentiated tumors $(p=0.027)$ and accordingly, the statistical analysis revealed significant associations between PR tumor cells immunoexpression and tumor grading.

The stromal expression for both steroid immunomarkers (ER and PR) has been significantly higher in EOC when compared to endometriosis stroma, $p=0.001$ and $p=0.000$, respectively. Moreover, the statistical analysis between stromal PR immunoexpression and tumor grading revealed significant associations $(p=0.005)$.

\section{ㅁ Discussions}

Endometriosis is a benign disease with an increasing incidence, probable due to the progresses registered in tools of diagnosis and population enhanced accessibility to these means.

The epidemiological data identified common risk factors, such as short menstrual periods, early menarche, nulliparity, late menopause, which are common for both endometriosis and OCs and there are also common potential protective factors for both diseases, such as oral contraceptives, high parity, tubal ligature, and hysterectomy [30].

The current state of knowledge shows that there are two pathways that appear to be involved in the endometriosis potential to progress towards neoplasia: either malignant transformation, perhaps through an atypical transitional stage, or a common precursor mechanism or predisposing factors is common in both processes, with a consecutive molecular divergence [31].

EOC occurs in $60-80 \%$ of cases in association with atypical endometriosis. Numerous studies have tried to identify a common model for endometriosis and EOC. The association of these two diseases has been identified most frequently in endometrioid OC, clear cell carcinoma (CCC), seromucinous carcinoma, endometrioid stromal sarcoma, and Müllerian adenosarcoma [32].

In most cases, these tumors are developed during the first decade from endometriosis diagnosis (70\%), and moreover they frequently display an intermediary stage of atypical endometriosis associated in most cases $(60 \%)$ [32]. Supplementary, because of endometriosis intrinsic invasive capacity and high metastatic ability, its biological behavior shows a strong homology with cancers [33].

Since a multitude of etiopathogenic mechanisms was proposed for endometriosis, a variable involvement of multiple processes may be related to location and lesional type, with the possibility that some of the phenomena may represent, in fact, consequences of an initial lesion.

One mechanism that has aroused the interest of researchers in the last decade is that of EMT, and its reverse process, MET, these being studied mainly in the carcinogenesis and metastasis process. EMT is a strictly controlled, reversible process characteristic for the embryogenesis period and can be also found during adulthood in epithelia with fast cell regeneration, such as epidermis and intestinal villi, in wound healing, and in pathological processes, such as fibrosis and inflammation [25]. EMT also occurs during carcinogenesis, being characterized by changes that give malignant cells a high potential for invasion and metastasis, respectively [25].

As E-cadherin is expressed in all epithelial cells, being involved in the maintenance of polarization and of cellular integrity [34], its loss represents a marker of EMT process [34]. An ablation of E-cadherin expression is noticed in EMT and, therefore, cells gain an increased mobility, allowing them invasion and metastasis abilities [34]. Thus, E-cadherin decreased expression is involved in a decisive way in the pathogenic mechanism of endometriosis, cells that lose expression having the same invasive and metastatic phenotype as carcinomatous cells [34].

Because ovarian endometriosis represents a clonal proliferation of cells with genetic alterations; this disease 
is considered a true neoplasm, a precursor of OC [7]. It is estimated that $\beta$-catenin mutations represent an early event in the endometriotic-dependent ovarian carcinogenesis sequence [7].

Endometriosis has been documented as a precursor lesion in $20-40 \%$ cases of endometrioid type and $40-55 \%$ of clear cell carcinoma (CCC) type of OC [7]. It has been also demonstrated that these malignancies are associated with endometriosis in 5-10\% of cases, adding an intermediary phase of atypical endometriosis only in $0.7-1.6 \%$ of cases, mainly in cases suffering from longstanding endometriosis [7].

Oncogenic mutations of phosphorylation site of $\beta$-catenin [catenin beta 1 (CTNNB1) gene] result in a stable protein formation, detected in $40-60 \%$ of EOC, in $52.4 \%$ of associated endometriosis, and in $73.3 \%$ of associated atypical endometriosis [7].

The alterations of E-cadherin, $\beta$-catenin, and CK18 are correlated to the progression along EMT process and to stages progression of EOC. An increased level of E-cadherin and $\beta$-catenin has been registered in the endometriosis group of our study and gradually decreased with the stages evolution of cases diagnosed with malignancy. This data suggests that its loss occurs late during the EMT process, being evident in the carcinogenesis process associated with endometriosis. Furthermore, the negative E-cadherin immunostaining score in our EOC group demonstrates the existence of the cadherinic switch, characteristic of the EMT process. Statistical analysis revealed in the investigated cases a significant difference between the Ecadherin immunostaining score in endometriosis versus $\operatorname{EOC}(p=0.001)$. We found that $\beta$-catenin showed a marked immunointensity in the endometriosis group, showing a slight decrease in the EOC group. $\beta$-catenin percentage of immunopositive tumor cells registered a slight decrease in EOC group. Statistical analysis revealed significant differences between the group of cases diagnosed with endometriosis and EOC $(p=0.000112)$. This suggests the gradual loss of epithelial features as the EMT process extends. Moreover, $\beta$-catenin registered $94.73 \%$ immunopositivity in endometrioid versus $100 \%$ in CCC, suggesting its value as a poor prognosis factor in EOC.

CK18, a type I cytokeratin belonging to the cytoskeleton, expressed both in glandular endometriotic cells [35] and in carcinomatous cells, is considered an immunomarker of morphological heterogeneity and of neoplastic changes [36], including those of OCs [37]. CK18 maintain its expression in endometrioid carcinomas or in those with an endometrioid component.

CK18 showed a high immunostaining index and percentage of positive cells as a specific immunomarker of endometriotic epithelial cells, demonstrating its involvement in apoptosis in the investigated cases [38], with statistically significant differences between the endometriotic and EOC groups ( $p=0.032468)$. In our study, in both components, intensity and immunopositive tumor cells, have registered evident changes in malignant group. Moreover, the malignant group showed a progressive reduction of the immunostaining index with the stage. This demonstrates the loss of epithelial phenotypic characteristics and the acquisition of a stromal phenotype, gradually according to the malignant process extension.

Although alterations of E-cadherin, $\beta$-catenin, and
CK18 have been recorded, the correlation analysis between EMT immunomarkers expression in endometriosis did not revealed significant differences but revealed statistically significant differences in EOC group, between E-cadherin and $\beta$-catenin, on one hand, and between E-cadherin and CK18 immunoexpression, on the other hand, in EOC group, in our study.

The correlation analysis between EMT immunomarkers (E-cadherin, $\beta$-catenin, and CK18) expression in EOC and clinicopathological characteristics (age, parity, menopausal status, tumor size, ovarian capsular invasion, histological type of EOC, FIGO, TNM stages, and CA125 serum values) did not reveal any statistically significant associations, suggestive of other factors interventions in this process.

Apoptosis, as a pivotal mechanism of regulation of variable cellular populations, normal and pathological, is mainly based on the antagonism between Bcl-2 and Bax [39]. Bcl-2 is preventing apoptosis without any effect on proliferation and protects against deoxyribonucleic acid (DNA)-induced apoptosis [40]. It is considered that Bcl2 has a relevant anti-apoptotic activity, depending on Bax involvement [41, 42]. Due to apoptosis involvement in carcinogenesis, tumor promoter or suppressor roles are attributed to Bcl-2. Due to its pro-apoptotic role, Bax has the characteristics of tumor suppressor role [43]. The endometriotic cells show a weak Bax immunoexpression, associated to a high Bcl-2 immunoexpression [44]. An enhanced rate $\mathrm{Bcl}-2 / \mathrm{Bax}$ has been demonstrated in $\mathrm{EOC}$, representing a possible prognosis immunomarker and, at the same time, creates the premises for $\mathrm{Bcl}-2$ antagonists and/or Bax agonists therapeutic use [8]. Furthermore, the $\mathrm{Bcl}-2 / \mathrm{Bax}$ ratio immunoexpression in EOC compared to endometriosis reflects the decreased ovarian cell sensitivity to apoptotic stimuli. In agreement with this data, it has been demonstrated that spontaneous endometriosis may be induced by Bax and may be prevented by Bcl-2 [16].

The expression of pro- and anti-apoptotic immunomarkers revealed low levels of Bax, associated with a slight increase of Bcl-2 in the epithelial component of the investigated cases. The data obtained are consistent with literature reports showing that the relationship between anti-apoptotic and pro-apoptotic factors appears to be involved in the etiopathogenesis of endometriosis [44, 45]. It has been also demonstrated that Bcl-2/Bax high rate in endometriosis is correlated to a high malignant potential [8]. The statistical correlation analysis revealed statistically significant differences between Bax and Bcl-2 immunoexpression in the endometriosis group $(p=0.020)$. Amplification of $\mathrm{Bcl}-2 / \mathrm{Bax}$ ratio demonstrates the progressive decrease in ovarian cell sensitivity to apoptotic signaling and contributes, along with the alteration of steroid receptor, to the transition mechanism to malignancy, opening new perspectives of prognosis and therapy improvement.

Although a significant difference has been identified between Bax and Bcl-2 immunoexpression in endometriosis, no statistically significant differences have been registered between the immunoexpression of Bax and Bcl-2 in EOC. Furthermore, no statistically significant differences have been registered between Bax and Bcl-2 immunoexpression and clinicopathological characteristics in both groups, suggesting the intervention of other factors.

Estrogens action, modulated by specific receptors, ERs, has effects on the production of cytokines and of 
apoptotic phenomena, in endometriosis [46], counterbalanced by progesterone action, modulated by their counterpart specific receptors, PRs [20, 47-49]. Different from eutopic endometrium, where steroid receptors level may be correlated with endometrial cycle phases, ER being strongly expressed in proliferative stage and decreasing its expression in both epithelial and stromal components in secretory phase, no cyclical changes have been noticed in endometriosis [50]. Moreover, a generally more reduced ER immunoexpression has been observed in endometriosis $[50,51]$. It is well-recognized the estrogen value as a stimulator factor of cell proliferation, in ovarian milieu, of the mobility of the malignant population of cells, and of the inhibition of the intercellular adhesions [22, 52]. Although in the secretory phase of eutopic endometrium, $\mathrm{PR}$ is strongly immunoexpressed, mainly in the stromal component, no cyclical changes of these receptors have been noticed in endometriosis [50], PRs showing a weak immunoexpression [50, 51]. Relatively new data have demonstrated the correlation between ER or PR immunoexpression and their clinical impact in OC [21,22].

In the current study, the hormonal receptors immunoexpression has been noticed in both components of endometriosis, epithelial and stromal. In comparative terms with their immunoexpression in eutopic and normal endometrium, a degree of difficulty in their interpretation occurs, considering that the hormones are responsible for the cyclical stimulation of proliferation and regeneration and of secretory function, in the secretory phase, respectively. Moreover, another recent theory, based on comparative studies between the different endometriotic locations and eutopic endometrium, is focused on paracrine inhibition of steroid receptors immunoexpression in ovarian endometriosis [51].

Consequently, although the steroid receptors levels are high in ovarian endometriosis, a moderately increased immunoexpression has been observed in our group of study, without any statistically significant correlations with clinicopathological characteristics.

Supplementary, PR immunoexpression has shown statistically significant differences according to ovarian location of endometriosis $(p=0.04)$. This finding is validating $\mathrm{PR}$ role in endometriosis mechanism, on one hand, and on the other hand, supports the influence of paracrine factors in ovarian microenvironment, responsible for differences observed from other locations, demonstrating a high susceptibility of ovarian endometriosis to malignant transformation.

ER immunostaining score in tumor cells was high in most cases of our study, displaying a strong nuclear immunostaining, demonstrating the hormonal influence in ovarian malignancies etiopathogenesis. A high epithelial immunoexpression of ER has been also detected in endometriosis, but displaying a heterogeneous immunoexpression. Although we would expect a concordance with literature data, no significant difference has been noticed between ER immunoexpression in tumor cells of endometrioid OC compared to non-endometrioid type in the investigated cases. These discrepancies are attributed probably to the limited number of cases available for our study or to the cut-off value.

Another interesting finding has been that of a weaker stromal ER immunoexpression in endometriosis in comparison to the tumor stroma $(p=0.001)$ and its significance can be related to a less responsive histological area to the hormone stimuli or maybe to a much lower immunoexpression of an ER isoform.

Regarding FIGO staging, no significant difference has been observed between PR immunoexpression in EOC epithelial and stromal cells in early stages compared to late stages in the studied group, although literature data show a higher PR immunoexpression in endometrioid histological pattern, in the absence of peritoneal metastases, showing a high correlation with tumor cells proliferation inhibition and with metastases development [22, 53, 54]. However, significant differences have been noticed between the epithelial $(p=0.027)$ and stromal PR immunoexpression $(p=0.005)$ in EOC with more differentiated histological types, suggesting a partial protective role of progesterone in carcinogenesis.

PR stromal immunoexpression has been significantly lower in endometriosis in comparison with tumor counterpart $(p=0.000)$, possible in correlation with an unbalanced estrogenic stimulus in endometriosis pathogenesis and a decreasing role of this stimulus in the development of EOC. The weaker PR immunoexpression both in epithelial cells and stromal elements of endometriosis suggests that loss of PR immunoexpression may be attributed to early genetic changes prior to morphological atypia, as an important IHC marker in endometriosis malignant transformation risk [55]. The IHC expression of steroid hormone receptors, associated to clinicopathological findings supports the transition mechanism of ovarian endometriosis towards EOC, with a potential use for a better evaluation of prognosis and opens new perspectives for the development of new therapies.

\section{ㅁ Conclusions}

Endometriosis can be considered a precursor lesion of EOC, as demonstrated in this study, and IHC expression of E-cadherin, $\beta$-catenin, Bcl-2, Bax, ER, and PR in corroboration with clinicopathological features supports the mechanism of transition of ovarian endometriosis into EOC, provides new prognosis tools, and opens new therapeutic perspectives. Considering the value of ovarian endometriosis as a precursor lesion for a large spectrum of OCs, the understanding of mechanisms which are involved in these diseases has also a prevention value for ovarian malignancies, with a beneficial effect for populations at high-risk.

\section{Conflict of interests}

The authors declare that they have no conflict of interests.

\section{References}

[1] D'Hooghe TM, Debrock S. Endometriosis, retrograde menstruation and peritoneal inflammation in women and in baboons. Hum Reprod Update, 2002, 8(1):84-88. https://doi.org/10. 1093/humupd/8.1.84 PMID: 11866244

[2] Kyama CM, Mihalyi A, Simsa P, Mwenda JM, Tomassetti C, Meuleman C, D'Hooghe TM. Non-steroidal targets in the diagnosis and treatment of endometriosis. Curr Med Chem, 2008, 15(10):1006-1017. https://doi.org/10.2174/09298670 8784049595 PMID: 18393858

[3] Strauss JF, Barbieri RL (eds). Yen \& Jaffe's reproductive endocrinology: physiology, pathophysiology, and clinical management. $7^{\text {th }}$ edition, Saunders-Elsevier, Philadelphia, 2014. 
[4] Sampson JA. Peritoneal endometriosis due to menstrual dissemination of endometrial tissue into the peritoneal cavity. Am J Obstet Gynecol, 1927, 14(4):422-469. https://doi.org/ 10.1016/S0002-9378(15)30003-X

[5] Hanahan D, Weinberg RA. The hallmarks of cancer. Cell, 2000, 100(1):57-70. https://doi.org/10.1016/s0092-8674(00) 81683-9 PMID: 10647931

[6] Matsuzaki J, Gnjatic S, Mhawech-Fauceglia P, Beck A, Miller A Tsuji T, Eppolito C, Qian F, Lele S, Shrikant P, Old LJ, Odunsi K. Tumor-infiltrating NY-ESO-1-specific CD8+ T cells are negatively regulated by LAG-3 and PD-1 in human ovarian cancer. Proc Natl Acad Sci U S A, 2010, 107(17):7875-7880. https://doi. org/10.1073/pnas.1003345107 PMID: 20385810 PMCID: PMC2867907

[7] Matsumoto T, Yamazaki M, Takahashi H, Kajita S, Suzuki E, Tsuruta T, Saegusa M. Distinct $\beta$-catenin and PIK3CA mutation profiles in endometriosis-associated ovarian endometrioid and clear cell carcinomas. Am J Clin Pathol, 2015, 144(3):452463. https://doi.org/10.1309/AJCPZ5T2POOFMQVN PMID: 26276776

[8] Zeren T, Inan S, Vatansever HS, Sayhanet S. Significance of apoptosis related proteins on malignant transformation of ovarian tumors: a comparison between Bcl-2/Bax ratio and p53 immunoreactivity. Acta Histochem, 2014, 116(8):1251-1258. https://doi.org/10.1016/j.acthis.2014.07.007 PMID: 25108507

[9] Gross A, McDonnell JM, Korsmeyer SJ. BCL-2 family members and mitochondria in apoptosis. Genes Dev, 1999 13(15):1899-1911. https://doi.org/10.1101/gad.13.15.1899 PMID: 10444588

[10] Fischer U, Janssen K, Schulze-Osthoff K. Does caspase inhibition promote clonogenic tumor growth? Cell Cycle, 2007, 6(24):3048-3053. https://doi.org/10.4161/cc.6.24.5118 PMID: 18073530

[11] Matias-Guiu X, Prat J. Molecular pathology of ovarian carcinomas. Virchows Arch, 1998, 433(2):103-111. https://doi.org/ 10.1007/s004280050224 PMID: 9737787

[12] Yamasaki F, Tokunaga O, Sugimori H. Apoptotic index in ovarian carcinoma. Gynecol Oncol, 1997, 66(3):439-448. https://doi.org/10.1006/gyno.1997.4783 PMID: 9299259

[13] Brustmann H. DNA fragmentation factor (DFF45): expression and prognostic value in serous ovarian cancer. Pathol Res Pract, 2006, 202(10):713-720. https://doi.org/10.1016/j.prp. 2006.06.003 PMID: 16962250

[14] Schorr K, Li M, Krajewski S, Reed JC, Furth PA. Bcl-2 gene family and related proteins in mammary gland involution and breast cancer. J Mammary Gland Biol Neoplasia, 1999 4(2):153-164. https://doi.org/10.1023/a:1018773123899 PMID: 10426394

[15] Correia-da-Silva G, Bell SC, Pringle JH, Teixeira NA. Patterns of expression of $B a x, B c l-2$ and $B c l-x(L)$ in the implantation site in rat during pregnancy. Placenta, 2005, 26(10):796-806. https://doi.org/10.1016/j.placenta.2004.09.008 PMID: 16226130

[16] Vatansever SH, Inan SV, Giray GS, Sayhan S, Ozbilgin KM, Sanci M. The distribution of apoptosis and related proteins in ovarian endometriosis. Saudi Med J, 2009, 30(6):855-856. PMID: 19526177

[17] Pearce CL, Templeman C, Rossing MA, Lee A, Near AM, Webb PM, Nagle CM, Doherty JA, Cushing-Haugen KL, Wicklund KG, Chang-Claude J, Hein R, Lurie G, Wilkens LR, Carney ME, Goodman MT, Moysich K, Kjaer SK, Hogdall E, Jensen A, Goode EL, Fridley BL, Larson MC, Schildkraut JM, Palmieri RT, Cramer DW, Terry KL, Vitonis AF, Titus LJ, Ziogas A, Brewster W, Anton-Culver H, Gentry-Maharaj A, Ramus SJ, Anderson AR, Brueggmann D, Fasching PA, Gayther SA, Huntsman DG, Menon U, Ness RB, Pike MC Risch H, Wu AH, Berchuck A; Ovarian Cancer Association Consortium. Association between endometriosis and risk of histological subtypes of ovarian cancer: a pooled analysis of case-control studies. Lancet Oncol, 2012, 13(4):385-394. https://doi.org/10.1016/S1470-2045(11)70404-1 PMID: 22361336 PMCID: PMC3664011

[18] Yu HC, Lin CY, Chang WC, Shen BJ, Chang WP, Chuang CM: Task Force on Carcinogenesis of Endometrial Cancer. Increased association between endometriosis and endometrial cancer: a nationwide population-based retrospective cohort study. Int J Gynecol Cancer, 2015, 25(3):447-452. https://doi.org/10.10 97/IGC.0000000000000384 PMID: 25695548 PMCID: PMC 4340602

[19] Xue Q, Lin Z, Cheng YH, Huang CC, Marsh E, Yin P, Milad MP, Confino E, Reierstad S, Innes J, Bulun SE. Promoter methylation regulates estrogen receptor 2 in human endometrium and endometriosis. Biol Reprod, 2007, 77(4):681-687. https:// doi.org/10.1095/biolreprod.107.061804 PMID: 17625110

[20] Monsivais D, Dyson MT, Yin P, Coon JS, Navarro A, Feng G, Malpani SS, Ono M, Ercan CM, Wei JJ, Pavone ME, Su E, Bulun SE. ER $\beta$ - and prostaglandin E2-regulated pathways integrate cell proliferation via Ras-like and estrogen-regulated growth inhibitor in endometriosis. Mol Endocrinol, 2014, 28(8): 1304-1315. https://doi.org/10.1210/me.2013-1421 PMID: 24992181 PMCID: PMC4116594

[21] Tkalia IG, Vorobyova LI, Svintsitsky VS, Nespryadko SV, Goncharuk IV, Lukyanova NY, Chekhun VF. Clinical significance of hormonal receptor status of malignant ovarian tumors. Exp Oncol, 2014, 36(2):125-133. PMID: 24980769

[22] Chen S, Dai X, Gao Y, Shen F, Ding J, Chen Q. The positivity of estrogen receptor and progesterone receptor may not be associated with metastasis and recurrence in epithelial ovarian cancer. Sci Rep, 2017, 7(1):16922. https://doi.org/10.1038/ s41598-017-17265-6 PMID: 29208958 PMCID: PMC5717220

[23] Chae U, Min JY, Kim SH, Ihm HJ, Oh YS, Park SY, Chae HD, Kim CH, Kang BM. Decreased progesterone receptor B/A ratio in endometrial cells by tumor necrosis factor-alpha and peritoneal fluid from patients with endometriosis. Yonsei Med J, 2016, 57(6):1468-1474. https://doi.org/10.3349/ymj.2016.57. 6.1468 PMID: 27593876 PMCID: PMC5011280

[24] Zhao C, Bratthauer GL, Barner R, Vang R. Comparative analysis of alternative and traditional immunohistochemical markers for the distinction of ovarian Sertoli cell tumor from endometrioid tumors and carcinoid tumor: a study of 160 cases. Am J Surg Pathol, 2007, 31(2):255-266. https://doi. org/10.1097/01.pas.0000213355.72638.f4 PMID: 17255771

[25] Sethi S, Sarkar FH, Ahmed Q, Bandyopadhyay S, Nahleh ZA, Semaan A, Sakr W, Munkarah A, Ali-Fehmi R. Molecular markers of epithelial-to-mesenchymal transition are associated with tumor aggressiveness in breast carcinoma. Transl Oncol, 2011, 4(4):222-226. https://doi.org/10.1593/tlo.10244 PMID: 21804917 PMCID: PMC3140009

[26] Suzuki Y, Honma T, Hayashi S, Ajioka Y, Asakura H. Bcl-2 expression and frequency of apoptosis correlate with morphogenesis of colorectal neoplasia. J Clin Pathol, 2002, 55(3):212 216. https://doi.org/10.1136/jcp.55.3.212 PMID: 11896074 PMCID: PMC1769608

[27] Zlobec I, Terracciano L, Jass JR, Lugli A. Value of staining intensity in the interpretation of immunohistochemistry for tumor markers in colorectal cancer. Virchows Arch, 2007, 451(4):763-769. https://doi.org/10.1007/s00428-007-0466-8 PMID: 17674041

[28] Allred DC, Harvey JM, Berardo M, Clark GM. Prognostic and predictive factors in breast cancer by immunohistochemical analysis. Mod Pathol, 1998, 11(2):155-168. PMID: 9504686

[29] Haidarali E, Vahedi A, Mohajeri S, Mostafidi E, Azimpouran M, Naghavi Behzad M. Evaluation of the pathogenesis of tumor development from endometriosis by estrogen receptor, p53 and bcl-2 immunohistochemical staining. Asian Pac J Cancer Prev, 2016, 17(12):5247-5250. https://doi.org/10.22034/APJ CP.2016.17.12.5247 PMID: 28125869 PMCID: PMC5454666

[30] Van Gorp T, Amant F, Neven P, Vergote I, Moerman P. Endometriosis and the development of malignant tumours of the pelvis. A review of literature. Best Pract Res Clin Obstet Gynaecol, 2004, 18(2):349-371. https://doi.org/10.1016/j.bp obgyn.2003.03.001 PMID: 15157647

[31] Varma R, Rollason T, Gupta JK, Maher ER. Endometriosis and the neoplastic process. Reproduction, 2004, 127(3):293-304. https://doi.org/10.1530/rep.1.00020 PMID: 15016949

[32] Taniguchi F. New knowledge and insights about the malignant transformation of endometriosis. J Obstet Gynaecol Res, 2017, 43(7):1093-1100. https://doi.org/10.1111/jog.13372 PMID: 28718209

[33] Zeitvogel A, Baumann R, Starzinski-Powitz A. Identification of an invasive, $\mathrm{N}$-cadherin-expressing epithelial cell type in endometriosis using a new cell culture model. Am J Pathol, 2001, 159(5):1839-1852. https://doi.org/10.1016/S0002-9440 (10)63030-1 PMID: 11696444 PMCID: PMC1867070

[34] Zhou B, Xu H, Xia M, Sun C, Li N, Guo E, Guo L, Shan W, Lu H, Wu Y, Li Y, Yang D, Weng D, Meng L, Hu J, Ma D, Chen G, Li K. Overexpressed miR-9 promotes tumor metastasis via targeting E-cadherin in serous ovarian cancer. Front Med, 2017, 11(2):214-222. https://doi.org/10.1007/s11684017-0518-7 PMID: 28470508 
[35] Klemmt PAB, Carver JG, Kennedy SH, Koninckx PR, Mardon HJ. Stromal cells from endometriotic lesions and endometrium from women with endometriosis have reduced decidualization capacity. Fertil Steril, 2006, 85(3):564-572. https://doi.org/ 10.1016/j.fertnstert.2005.08.046 PMID: 16500320 PMCID: PMC1626574

[36] Trisdale SK, Schwab NM, Hou X, Davis JS, Townson DH. Molecular manipulation of keratin 8/18 intermediate filaments: modulators of FAS-mediated death signaling in human ovarian granulosa tumor cells. J Ovarian Res, 2016, 9:8. https://doi. org/10.1186/s13048-016-0217-z PMID: 26911253 PMCID: PMC4765146

[37] Duncan A, Forcina J, Birt A, Townson D. Estrous cycledependent changes of Fas expression in the bovine corpus luteum: influence of keratin 8/18 intermediate filaments and cytokines. Reprod Biol Endocrinol, 2012, 10:90. https://doi. org/10.1186/1477-7827-10-90 PMID: 23113883 PMCID: PMC3567950

[38] Moll R, Divo M, Langbein L. The human keratins: biology and pathology. Histochem Cell Biol, 2008, 129(6):705-733. https://doi.org/10.1007/s00418-008-0435-6 PMID: 18461349 PMCID: PMC2386534

[39] Petros AM, Olejniczak ET, Fesik SW. Structural biology of the Bcl-2 family of proteins. Biochim Biophys Acta, 2004 1644(2-3):83-94. https://doi.org/10.1016/j.bbamcr.2003.08. 012 PMID: 14996493

[40] Simonin K, Brotin E, Dufort S, Dutoit S, Goux D, N'diaye M, Denoyelle C, Gauduchon P, Poulain L. Mcl-1 is an important determinant of the apoptotic response to the BH3-mimetic molecule HA14-1 in cisplatin-resistant ovarian carcinoma cells Mol Cancer Ther, 2009, 8(11):3162-3170. https://doi.org/10. 1158/1535-7163.MCT-09-0493 PMID: 19887550

[41] Korsmeyer SJ, Wei MC, Saito M, Weiler S, Oh KJ, Schlesinger PH. Pro-apoptotic cascade activates BID, which oligomerizes BAK or BAX into pores that result in the release of cytochrome c. Cell Death Differ, 2000, 7(12):1166-1173. https://doi.org/10.1038/sj.cdd.4400783 PMID: 11175253

[42] Lozneanu L, Cojocaru E, Giuşcă SE, Cărăuleanu A, Căruntu ID. Lesser-known molecules in ovarian carcinogenesis. Biomed Res Int, 2015, 2015:321740. https://doi.org/10.1155/2015/ 321740 PMID: 26339605 PMCID: PMC4538335

[43] Cartron PF, Oliver L, Martin S, Moreau C, LeCabellec MT, Jezequel P, Meflah K, Vallette FM. The expression of a new variant of the pro-apoptotic molecule Bax, Baxpsi, is correlated with an increased survival of glioblastoma multiforme patients Hum Mol Genet, 2002, 11(6):675-687. https://doi.org/10.1093/ hmg/11.6.675 PMID: 11912183

[44] Meresman GF, Vighi S, Buquet RA, Contreras-Ortiz O, Tesone M, Rumi LS. Apoptosis and expression of Bcl-2 and Bax in eutopic endometrium from women with endometriosis. Fertil Steril, 2000, 74(4):760-766. https://doi.org/10.1016/s 0015-0282(00)01522-3 PMID: 11020520

[45] Goumenou A, Panayiotides I, Matalliotakis I, Vlachonikolis I, Tzardi M, Koumantakis E. Bcl-2 and Bax expression in human endometriotic and adenomyotic tissues. Eur J Obstet Gynecol Reprod Biol, 2001, 99(2):256-260. https://doi.org/10.1016/s 0301-2115(01)00381-5 PMID: 11788183

[46] Han SJ, Jung SY, Wu SP, Hawkins SM, Park MJ, Kyo S, Qin J Lydon JP, Tsai SY, Tsai MJ, DeMayo FJ, O'Malley BW. Estrogen receptor $\beta$ modulates apoptosis complexes and the inflammasome to drive the pathogenesis of endometriosis. Cell, 2015, 163(4):960-974. https://doi.org/10.1016/j.cell.2015. 10.034 PMID: 26544941 PMCID: PMC4640214
[47] Lee DH, Kim SC, Joo JK, Kim HG, Na YJ, Kwak JY, Lee KS. Effects of $17 \beta$-estradiol on the release of monocyte chemotactic protein-1 and MAPK activity in monocytes stimulated with peritoneal fluid from endometriosis patients. J Obstet Gynaecol Res, 2012, 38(3):516-525. https://doi.org/10.1111/ j.1447-0756.2011.01734.x PMID: 22381103

[48] Veillat V, Carli C, Metz CN, Al-Abed Y, Naccache PH, Akoum A. Macrophage migration inhibitory factor elicits an angiogenic phenotype in human ectopic endometrial cells and triggers the production of major angiogenic factors via CD44, CD74, and MAPK signaling pathways. J Clin Endocrinol Metab, 2010, 95(12):E403-E412. https://doi.org/10.1210/jc.2010-0417 PMID: 20829186

[49] Khan KN, Kitajima M, Inoue T, Fujishita A, Nakashima M Masuzaki H. 17 $\beta$-Estradiol and lipopolysaccharide additively promote pelvic inflammation and growth of endometriosis. Reprod Sci, 2015, 22(5):585-594. https://doi.org/10.1177/ 1933719114556487 PMID: 25355803 PMCID: PMC4519769

[50] Calcagno A, Grassi T, Mariuzzi L, Marzinotto S, Londero AP, Orsaria M, Beltrami CA, Marchesoni D. Expression patterns of Aurora A and B kinases, Ki-67 and the estrogen and progesterone receptors determined using an endometriosis tissue microarray model. Hum Reprod, 2011, 26(10):27312741. https://doi.org/10.1093/humrep/der264 PMID: 21840910

[51] Suzuki A, Horiuchi A, Oka K, Miyamoto T, Kashima H, Shiozawa T. Immunohistochemical detection of steroid receptor cofactors in ovarian endometriosis: involvement of downregulated $S R C-1$ expression in the limited growth activity of the endometriotic epithelium. Virchows Arch, 2010, 456(4): 433-441. https://doi.org/10.1007/s00428-010-0884-x PMID: 20155281

[52] Park SH, Cheung LWT, Wong AST, Leung PCK. Estrogen regulates Snail and Slug in the down-regulation of E-cadherin and induces metastatic potential of ovarian cancer cells through estrogen receptor alpha. Mol Endocrinol, 2008, 22(9):20852098. https://doi.org/10.1210/me.2007-0512 PMID: 18550773 PMCID: PMC5419456

[53] Sieh W, Köbel M, Longacre TA, Bowtell DD, deFazio A, Goodman MT, Høgdall E, Deen S, Wentzensen N, Moysich KB, Brenton JD, Clarke BA, Menon U, Gilks CB, Kim A, Madore J, Fereday S, George J, Galletta L, Lurie G, Wilkens LR, Carney ME, Thompson PJ, Matsuno RK, Kjær SK, Jensen A, Høgdall C Kalli KR, Fridley BL, Keeney GL, Vierkant RA, Cunningham JM, Brinton LA, Yang HP, Sherman ME, García-Closas M, Lissowska J, Odunsi K, Morrison C, Lele S, Bshara W, Sucheston L, Jimenez-Linan M, Driver K, Alsop J, Mack M, McGuire V, Rothstein JH, Rosen BP, Bernardini MQ, Mackay $\mathrm{H}$, Oza A, Wozniak EL, Benjamin E, Gentry-Maharaj A, Gayther SA, Tinker AV, Prentice LM, Chow C, Anglesio MS, Johnatty SE, Chenevix-Trench G, Whittemore AS, Pharoah PD, Goode EL, Huntsman DG, Ramus SJ. Hormone-receptor expression and ovarian cancer survival: an Ovarian Tumor Tissue Analysis consortium study. Lancet Oncol, 2013, 14(9):853-862. https:// doi.org/10.1016/S1470-2045(13)70253-5 PMID: 23845225 PMCID: PMC4006367

[54] Worley MJ, Welch WR, Berkowitz RS, Ng SW. Endometriosisassociated ovarian cancer: a review of pathogenesis. Int $\mathrm{J}$ Mol Sci, 2013, 14(3):5367-5379. https://doi.org/10.3390/ijms 14035367 PMID: 23466883 PMCID: PMC3634491

[55] Xiao W, Awadallah A, Xin W. Loss of ARID1A/BAF250a expression in ovarian endometriosis and clear cell carcinoma. Int J Clin Exp Pathol, 2012, 5(7):642-650. PMID: 22977660 PMCID: PMC3438773

\section{Corresponding authors}

Ludmila Lozneanu, Lecturer, MD, PhD, Department of Morphofunctional Sciences I - Histology, Grigore T. Popa University of Medicine and Pharmacy, 16 Universităţii Street, 700115 laşi, Romania; Phone +40744-341 459, e-mail: ludmila.lozneanu@umfiasi.ro

Raluca Anca Balan, Associate Professor, MD, PhD, Department of Morphofunctional Sciences I - Histology, Grigore T. Popa University of Medicine and Pharmacy, 16 Universităţii Street, 700115 laşi, Romania; Phone +40720-550 530, e-mail: raluca.balan@umfiasi.ro 